\title{
The Study on Corporate Social Responsibility Affects Innovative Behavior
}

\author{
Huang Chi-fen, Lin Jer-Yan \\ Feng Chia University \\ E-mail address feeling0628@gmail.com
}

\begin{abstract}
Corporate social responsibility has received increasing necessary attention from scholars and practitioners in recent years. Businesses are expected to play the role of a corporate citizen in the community to obtain more substantial benefits. Corporate social responsibility has become an international tendency,

Corporate Social Responsibility plans should identify the most necessary strategic value in several areas, and find out the topics of most Creating Shared Value, while the creation of social wellbeing, enhance their competitive advantage, will probably be a vital factor in the company's future of success. The 262 effective questionnaires were adopted in this study.

The results of the study found that the Creating Shared Value has a significantly positive effect on Corporate Social Responsibility, the Corporate Cultural Characteristics is positively significant to Corporate Social Responsibility, and Corporate Social Responsibility has a significant positive effect on Innovative Behavior.
\end{abstract}

Keywords: Cultural Characteristics, Creating Shared Value, Corporate Social Responsibility, Innovative Behavior

\section{INTRODUCTION}

This is an open access article under the CC-BY-NC license.

Advances in technology and industry have brought convenience to life and also brought a lot of pollution. In the past, the main goal of enterprises was to maximize profits. Therefore, the interests of employees, customer rights, and the natural environment were not taken seriously. Then, unlike the situation of pursuing huge profits in the past, when manufacturers conduct business activities, in addition to considering their own operating profits, they will also start to think about their customers' rights and interests, the public, and so on. Social responsibility is the key to an enterprise's goal of excellence. Porter \& Kramer (2006) believes that the purpose of an enterprise must be redefined as the creation of "shared value," not just the pursuit of profit. Shared value is not limited to social responsibility, charity, and public welfare activities, but a new way for the company to achieve economic success. In this way, the combination of corporate social responsibility and business strategy will be the source of a company's new competitiveness in the future, making shared value and corporate social responsibility a topic that companies have to pay attention to when facing the trend of globalization. In recent years, most companies have taken creativity and innovation as their vision for their future development. Innovation is an important tool for companies to maintain their 
competitive advantage, and it is also an important key to their long-term survival and enhancement of competitiveness (Tran, 2006; Lin, 2006; Chang \& Lee, 2007; Gordon et al., 2008), the profit creation of enterprises provides the needs of society, while society provides the space and resources for enterprises to create wealth. Therefore, there must be relative expectations and ideas between enterprises and society. Only innovation can lead to development; innovation leads to competitiveness. Enterprises must continue to innovate to meet future challenges and to meet the trend of the times.

In recent years, government agencies, investors, employees, and the general public have gradually increased their requirements for corporate social responsibility, and it has become one of the important sources of corporate management and competition pressure. Therefore, companies can improve the corporate system through corporate governance mechanisms and checks and balances. Enhance corporate competitiveness, create shareholder rights, and better fulfill corporate social responsibility.

The purpose of this study:

(1) Explore how the value activity strategy has an impact on corporate social responsibility activities.

(2) From the perspective of employees, study the impact of corporate cultural characteristics and corporate social responsibility activities.

(3) Explore the impact of corporate social responsibility on employee innovation behavior.

\section{LITERATURE REVIEW}

\section{II.1 Relationship Between Creating Shared Value and Corporate Social Responsibility}

The company's corporate shared value (SV) strategy is closely related to the company's profitability and competitive position; SV seeks to expand economic and social value, which is a powerful force that promotes global economic growth ( Porter \& Kramer, 2011).

Zairi and Peters (2002) pointed out that when a company fulfills its social responsibilities, it will have a positive impact on the company's image and help maintain its competitive advantage. Companies must link performance with social progress, regard shared value as a source of growth, and create profits for themselves through social needs, enhance competitiveness, and improve the economic and social environment in the region so that both themselves and society Be profitable.

Schmitt and Renken (2012) believe that shared value is a differentiated strategy that can provide valuable competitive opportunities. Companies have the responsibility to contribute to society and the environment, and all of the company's investments should return value to the company in order to achieve the goal of sharing the blessings of the company and society. In short, CSR strategies need to find a value strategy shared by the company and society, and A shared value strategy that can take into account both the "inside-out" and "outside-in" levels. The company's strategic activities are to promote some projects that can create clear and substantial benefits for the society and the company and can take into account both the "inside-out" and "outside-in" levels. This influential program is not only in line with the direction of the company's strategy but also in sync with the company's activities (Kuehn and Mclntire, 2014). Therefore, this research intends to use the empirical results to refer to the research of Porter and Kramer (2011) and Zairi \& Peters (2002), and propose the following hypotheses:

H1: Shared value has a positive impact on the rights and interests of customers and the general public in corporate social responsibility. 


\section{II.2 Relationship Between Corporate Cultural Characteristics and Corporate Social Responsibility}

The establishment of corporate culture Characteristics (CC) is a continuous process and requires disciplinary action. Various cultural attributes contain rich meanings. Family culture can provide organization members or customers with better service quality (Beek \& Gerritse, 2010). Different cultural attributes help understand the affiliation and characteristics of enterprises. Some excellent enterprises have specific cultural characteristics, taking social responsibility into account. So that they treat their employees and customers more friendly. And propose the following hypotheses:

H2: Corporate culture Characteristics has a positive impact on corporate social responsibility

\section{II.3 Relationship between Corporate Social Responsibility and innovative Behavior}

CSR is for sustainable development, and the means for sustainable development must be through continuous innovation and research and development of products. Vilanova et al. (2009) believe that competitive companies are achieved through innovation. The performance of CSR can also improve the corporate image and create corporate reputation due to the investment in CSR so that the company can always have a competitive advantage. Nikodemus (2016) researched that employee creativity and innovative Behavior are the foundation for organizations to improve creativity and innovation performance. The generation and realization of employees' innovative ideas is already a key performance that cannot be ignored in the organization; Janssen (2000) believes that innovative Behavior is employee Creative creation, application and application of new ideas are aimed at enabling employees, teams, and organizations to achieve higher and better performance. Hammond et al. (2011) further pointed out that innovation is an important key factor to create and maintain organizational competitiveness. In recent years, due to the rapid changes in the overall industrial environment, to sustainably operate and enhance competitiveness, while taking into account social interests, when promoting CSR decisions, companies will consider how to create social value while pursuing economic value. the company will set up a CSR research team, through the CSR committee meeting, through the knowledge sharing of members, to encourage employees' creative thinking, promote CSR innovation strategies, and generate innovation benefits. However, Padgett and Galan (2010) believe that innovation and CSR can improve social well-being and meet the expectations of shareholders, both can have a positive impact on the company, and propose the following hypotheses:

H3: Corporate social responsibility has a positive correlation to the team innovation and organizational innovation of innovative Behavior.

\section{RESEARCH METHODOLOGY}

\section{III.1 Research Framework}

In this paper, we will focus on CSR in 2015 and 2016, CommonWealth magazine and Finance magazine issued by Taiwan. Most award-winning firms were categorized in the classification by large enterprises, medium-sized enterprises, and little giants. As a research object, we explore Creating Shared Value, Corporate Cultural Characteristics, Corporate Social Responsibility, Innovative Behavior relevance. 


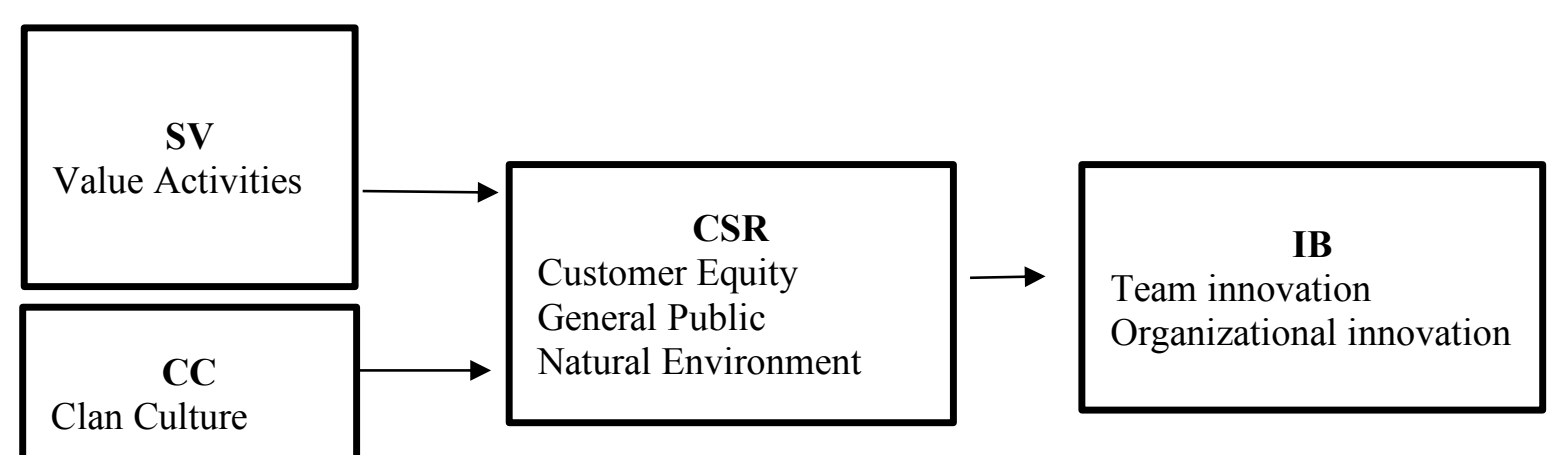

Figure 1 Research

\section{III.2 Questionnaire Design and Measures}

In this article, through reviewing related research and design, we will understand the project on the dimensions of Corporate Cultural Characteristics, Creating Shared Value, Corporate Social Responsibility, and Innovative Behavior. The measures corresponding to each construct are shown in Table 1.

Table1.Questionnaire items

\begin{tabular}{|c|c|c|}
\hline Variable & Items & References \\
\hline $\mathrm{CC}$ & Competitive value framework with six items. & $\begin{array}{l}\text { Cameron and Quinn, } \\
2006\end{array}$ \\
\hline SV & $\begin{array}{l}\text { corporate value activities by the modified seven items in } \\
\text { this dimension. }\end{array}$ & $\begin{array}{l}\text { Zairi and Peters, 2002; } \\
\text { Porter and Kramer, 2011 }\end{array}$ \\
\hline CSR & $\begin{array}{l}\text { The Corporate Social Responsibility (customer equity, } \\
\text { the general public, natural environment) with } 15 \text { items. }\end{array}$ & Duygu, 2009 \\
\hline IB & $\begin{array}{l}\text { Innovative Behavior (team innovation and organizational } \\
\text { innovation) with ten items. }\end{array}$ & $\begin{array}{l}\text { Janssen, 2000; } \\
\text { King and Anderson, } \\
2002 \text {, }\end{array}$ \\
\hline
\end{tabular}

In this study, the questionnaire included 38 items, which were measured and analyzed on a 6point Likert scale from 1 (strongly disagree) to 6 (strongly agree).

The 262 effective questionnaires were adopted in this study, questionnaire survey employees of firms listed in the 2015 and 2016 Corporate Social Responsibility Award List compiled by CommonWealth Magazine. Descriptive statistics, factor analysis, and reliability analysis were conducted through SPSS 21.0, and Lisrel 8.72 were used to analyze the data, is used to verify the reliability, consistency, and validity of the hypotheses and the questionnaire.

This research analyzes effective responses to test and propose hypotheses. SPSS 21.0 and structural equation modeling Lisrel 8.72 for sample statistics and description, narrative statistical analysis, reliability and validity analysis, confirmatory factor analysis, regression analysis, and use for data analysis.

\section{FINDING AND DISCUSSION}

\section{IV.1 Reliability and Descriptive Statistics}

We use online questionnaires to collect and survey data and manage these questionnaires electronically. Cronbach's $\alpha$ in all dimensions exceeds the recommended level of 0.7 , in which 0.935 for the innovative Behavior, 0.945 for corporate cultural characteristics, 0.948 for corporate social responsibility, and 0.952 for creating shared value activities. 
This study intends to initially observe the validity of the questionnaire through descriptive statistical analysis, as shown in Table 2 below.

Table 2. Descriptive Statistics ( $\mathrm{N}=262)$

\begin{tabular}{|c|l|l|l|c|l|l|}
\hline \multicolumn{2}{|l}{ variable } & Items & means & $\begin{array}{c}\text { Standard } \\
\text { deviation }\end{array}$ & skewness & kurtosis \\
\hline SV & Value Activities & 7 & 4.7563 & 0.8337 & -0.967 & 1.595 \\
\hline CC & Clan Culture & 6 & 4.3842 & 0.8594 & -0.316 & 0.294 \\
\hline \multirow{3}{*}{ CSR } & Customer equity & 7 & 4.8550 & 0.6962 & -0.597 & 0.21 \\
\cline { 2 - 7 } & General Public & 4 & 4.6937 & 0.8232 & -0.751 & 1.354 \\
\cline { 2 - 7 } & Natural Environment & 4 & 4.5105 & 0.9537 & -0.635 & 0.865 \\
\hline \multirow{2}{*}{ IB } & Team innovation & 3 & 4.5407 & 0.8185 & -0.621 & 1.148 \\
\cline { 2 - 7 } & $\begin{array}{l}\text { Organizational } \\
\text { innovation }\end{array}$ & 7 & 4.5262 & 0.8013 & -0.826 & 1.392 \\
\hline
\end{tabular}

\section{IV.2 Exploratory Factor Analysis}

This study intends to use factor analysis to verify the validity of the questionnaire, mainly adopting Principal Component extraction to conduct exploratory factor analysis, and using Varimax Solution as the axis of rotation, so that the factor load on the common factors after the axis of rotation is as large as possible.

The adequacy of each dimension is checked by the Kaiser-Meyer-Olkin (KMO) measure and the corresponding Bartlett test. The maximum KMO is organizational innovation (0.919) and the minimum to team innovation (0.747). The P-value by Bartlett test to all dimensions is 0.000 , which are all significant. The results are presented in Table 3. It means that the data of this research is suitable for further development of exploratory factor analysis.

Table3 Principal Component Analysis ( $\mathrm{N}=262)$

\begin{tabular}{|c|l|c|c|c|c|c|}
\hline \multicolumn{2}{|c|}{ Variable } & Kmo & Bartlett & P-Value & Eigenvalue & $\%$ \\
\hline SV & Value Activities & 0.908 & 1647.543 & 0.000 & 5.273 & 75.336 \\
\hline CC & Clan Culture & 0.878 & 1259.023 & 0.000 & 4.460 & 74.332 \\
\hline \multirow{3}{*}{ CSR } & Customer equity & 0.842 & 1036.503 & 0.000 & 4.232 & 60.464 \\
\cline { 2 - 7 } & General Public & 0.752 & 462.273 & 0.000 & 2.728 & 68.197 \\
\cline { 2 - 7 } & $\begin{array}{l}\text { Natural } \\
\text { Environment }\end{array}$ & 0.825 & 942.771 & 0.000 & 3.326 & 83.148 \\
\hline \multirow{2}{*}{ IB } & $\begin{array}{l}\text { Team } \\
\text { innovation }\end{array}$ & 0.744 & 429.003 & 0.000 & 2.438 & 81.251 \\
\cline { 2 - 7 } & $\begin{array}{l}\text { Organizational } \\
\text { innovation }\end{array}$ & 0.919 & 1401.868 & 0.000 & 5.019 & 71.706 \\
\hline
\end{tabular}

\section{IV.3 Validation by Confirmatory Factor Analysis}

In the process of showing validity by confirmatory factor analysis, the iterative search process must be used to obtain the best solution. Different indicators can be used to determine the appropriateness of the validation. The commonly used indicators are explained in detail below (Joreskog and Sorbom, 1989). As shown in table 4, NFI is 0.95,0.94,0.88, 0.92, and 0.97, respectively, and all NFI values are greater than 0.8 . NNFI is still reasonable to fit index, except the general public 0.77 being close to 0.8 . CFI are $0.96,0.94,0.89,0.92,0.97$ in which they are larger than 0.8 . GFI is greater than or close to 0.85 , and they are a reasonable fit index. Therefore, the above results show that only a small part of the fit index is not met, and most of the fit index meets the standard. Thus, the method is appropriate in this case. 
Table 4. Confirmatory Factor Analysis

\begin{tabular}{|c|c|c|c|c|c|c|}
\hline & $\begin{array}{l}\text { Chi- } \\
\text { Square }\end{array}$ & NFI & NNFI & CFI & GFI & RMR \\
\hline Value Activities & 131.35 & 0.95 & 0.94 & 0.96 & 0.87 & 0.036 \\
\hline Clan Culture & 123.92 & 0.94 & 0.90 & 0.94 & 0.86 & 0.047 \\
\hline Customer equity & 192.66 & 0.88 & 0.83 & 0.89 & 0.83 & 0.062 \\
\hline General Public & 43.57 & 0.92 & 0.77 & 0.92 & 0.92 & 0.067 \\
\hline Natural Environment & 12.52 & 0.97 & 0.91 & 0.97 & 0.94 & 0.030 \\
\hline Team innovation & 0.0 & \multicolumn{5}{|c|}{$\begin{array}{l}\text { The Model is Saturated, the Fit is } \\
\text { Perfect! }\end{array}$} \\
\hline $\begin{array}{l}\text { Organizational } \\
\text { innovation }\end{array}$ & 85.17 & 0.97 & 0.96 & 0.97 & 0.91 & 0.032 \\
\hline
\end{tabular}

\section{IV.4 Lisrel Structural Model}

Creating shared value is a significant and positive impact on corporate social responsibility $(\mathrm{p}<.05)$. Corporate cultural characteristics are also a significant positive effect on corporate social responsibility $(\mathrm{p}<.05)$. Corporate social responsibility has a significant and positive relationship with innovative Behavior $(\mathrm{p}<.05)$. All results show that three hypotheses are supported.

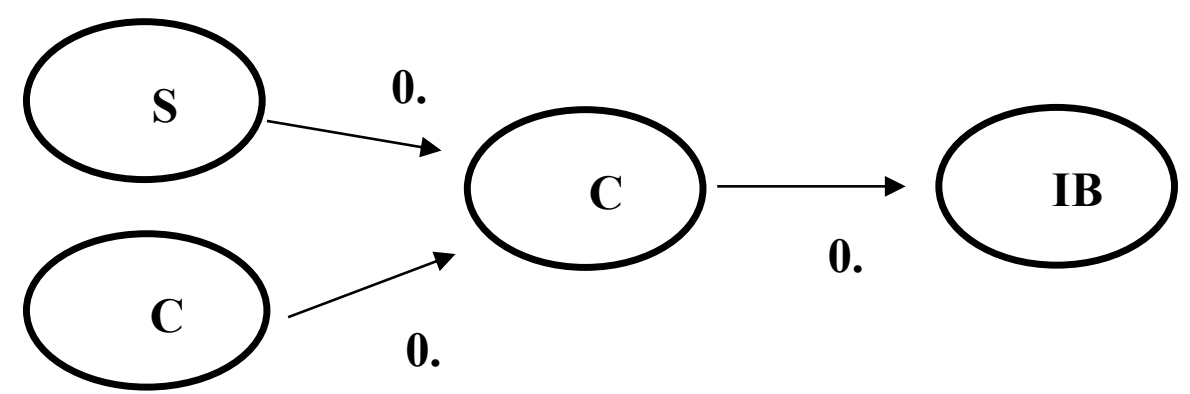

Figure 2. Lisrel Structural Model

\section{CONCLUSION AND FURTHER RESEARCH}

The results of this study show that there is a significant positive correlation between the emphasis on value activity strategies and the importance of employees to CSR in companies oriented towards CSR.

This proves that enterprise value and competitiveness are associated with Corporate Social Responsibility; Corporate Social Responsibility-minded firms should be collaborating with competitors to participate in value chain activities.

They tend to improve environmental well-being activities, engage in environmental improvement and protection, conduct environmentally sound investment activities, and purchase environmentally-friendly facilities.

Although Corporate Social Responsibility requires expensive costs to purchase environmental protection facilities and certifications, it may result in high costs for the implementation of relevant 
business opportunities and reduce financial performance in the short term; however, it may have good results for the company's long-term development.

The research results show that organizations have a positive attitude towards investing in CSR, and Organization levels and CSR are positively correlated.

Also, employees can help their organizations participate in the corporate social responsibility evaluation of the magazine, that is, the idea of corporate social responsibility implementation, which can improve work processes or formulate practical policies (improve organizational performance) and introduce them into corporate operations.

Innovative Behavior can encourage employees to participate in corporate social responsibility activities and create more new ideas. In terms of team innovation, companies or employees with innovative ideas are praised and rewarded, and employees' innovative ideas have developed feasible and practical cases and implemented them effectively at work. In terms of organizational innovation, the company will actively adopt new policies to improve performance; supervisors will use new leadership methods, supervisors will also understand employee goals, and will adjust the work of colleagues on time to successfully achieve the goals.

\section{REFERENCES}

Beek, A.P.A., \& Gerritsen, D.L. (2010). "The relationship between organizational culture of nursing staff and quality of care for residents with dementia: Questionnaire surveys and systematic observations in nursing homes." International Journal of Nursing Studies, In Press.

Cameron, K. S. \& Quinn, R. E. (2006). "Diagnosing and changing organizational culture based on the competing values framework" (Revised Ed.). New York, John Wiley And Sons Ltd

Chang, S. C., \& Lee, M. S. (2007). "The effects of organizational culture and knowledge management mechanisms on organizational innovation: An empirical study in Taiwan." The Business Review, Cambridge, vol. 7(1), pp. 295-301.

Duygu Turker (2009). Measuring Corporate Social Responsibility: A Scale Development Study. Journal of Business Ethics 85: 411-427

Gordon, S., Tarafdar, M., Cook, R., Masksimoski, R., \& Rogowitz, B.(2008). "Improving the front end of innovation with information technology." Research-Technology Management, vol. 51(3), pp. 50-58

Hammond, M. M., Neff, N. L., Farr, J. L., Schwall, A. R., \& Zhao, X. (2011). Predictors of individual-level innovation at work: A meta-analysis. Psychology of Aesthetics, Creativity, and the Arts, 5(1), 90.

Janssen, O. (2000). Job demands, perceptions of effort-reward fairness, and innovative work behavior. Journal of Occupational and Organizational Psychology, 73, 287-302.

King, N \& Anderson, N. (2002). "Managing innovation and chang: A critical guide for organization." London: Thomson.

Kuehn K. and Mclntire, L (2014). "Sustainability a CFO Can Love," Harvard Business Review, April

Lin, C. Y. (2006). "A study on the organizational innovations in Taiwan's logistics industry."The Business Review, Cambridge, vol. 5(1), pp. 270-275.

Nikodemus H. S.,(2016) "Enhancing Creativity and Innovative Behavior through Transformational Leadership and Psychological Empowerment: From the Lens of Self-Determination Theory" National Success University Ph.D.,2016.

Padgett, R. C., and Galan, J. I. (2010), The Effect of R\&D Intensity on Corporate Social Responsibility, Journal of Business Ethics, 93(3), 407-418.

Porter, M. E., and Kramer, M. R. (2006). "Strategy and society: The link between competitive advantage and corporate social responsibility." Harvard Business Review, December vol. 84(12), pp. 73-78, 78-92. 
Porter, M. E., and Kramer, M. R. (2011). "Creating Shared Value," Harvard Business Review January-February

Schmitt, J., \& Renken, U. (2012). "How to earn money by doing good: Shared value in the apparel industry." Journal of Corporate Citizenship, vol. 45, pp. 79-103.

Tran, T. T. (2006). "A Conceptual Model of Learning Culture and Innovation Schema." Competition Forum, vol. 4(1), ABI/INFORM Global, pp. 116-124.

Vilanova, M., Maria Lozano and Daniel Arenas (2009), "Exploring the Nature of the Relationship Between CSR and Competitiveness," Journal of Business Ethics, 87, 57-69.

Zairi, M., and Peters, J. (2002). The impact of social responsibility on business performance, Managerial Auditing Journal, 17(4), 174-178. 